\title{
DETERMINING OF THE MODULUS OF ELASTICITY BY MEASUREMENT OF THE RELATIVE STRAINS WITH STRAIN GAGES
}

\author{
LABAŠOVÁ Eva - LABAŠ Vladimír, SK
}

\begin{abstract}
The contribution is focused on estimating the Young modulus of the testing sample of rectangular cross-section by static method. The sample (bar) was loaded by simple bending. Theoretical basis for determining the modulus of elasticity are determined by linear elasticity and strength theory and they define the relation between Young modulus, maximum normal stress at the edge fibers of the crosssection and the relative strains. Relative strains are determined by using measurement apparatus and measurement system Quantum X MX 840. The aim of the work is to increase intellectual and practical skills of students in second and third level of technical universities.
\end{abstract}

Key words: Young modulus, simple bending, stress in the cross-section, relative strain.

\section{URČENIE MODULU PRUŽNOSTI V ŤAHU MERANÍM POMERNÝCH DEFORMÁCIÍ TENZOMETRAMI}

\section{Resumé}

Príspevok je zameraný na určenie modulu pružnosti v t’ahu pre skúšobnú tyč obdĺžnikového prierezu statickou metódou. Tyč bola namáhaná prostým ohybom. Teoretické východiská pre určenie modulu pružnosti v t'ahu sú založené na poznatkoch z lineárnej pružnosti a pevnosti a vyjadrujú súvis medzi modulom pružnosti v t’ahu, maximálnym normálovým napätím v krajných vláknach prierezu tyče a pomernou deformáciou. Pomerné deformácie sa stanovili na základe merania na zostavenej meracej aparatúre a meracej ústredne Quantum X MX 840. Práca podporuje zvyšovanie intelektuálnych a praktických zručností študentov na druhom a tret'om stupni technických univerzít.

Kl'účové slová: modul pružnosti v t’ahu, prostý ohyb, napätie v priečnom priereze, pomerná deformácia

\section{Introduction}

Modulus of elasticity is a material constant that represents the elastic properties of the materials. Size of this parameter depends mainly on type of the material. Modulus of elasticity or Young modulus $(E)$ and coefficient of transverse deformation or Poisson ratio $(\mu)$ are two independent constants that occur in a linear dependences between stress and strain tensors. Young's modulus is defined as the ratio of the stress and of the deformation that was induced by the stress (Hooke's Law) [1]:

$$
E=\frac{\sigma}{\varepsilon}
$$

where $E[\mathrm{~Pa}]$ is the Young modulus, $\sigma[\mathrm{Pa}]$ is the tensile (normal) stress, $\varepsilon[-]$ is the relative strain. $\varepsilon=\frac{\Delta l}{l}, \Delta l$ is extension (or reducing) of body for a given load, $l$ is original length of the body. $\sigma=\frac{F}{S}, F[\mathrm{~N}]$ is size of the load force that acts perpendicular to the cross-section $S\left[\mathrm{~m}^{2}\right]$.

Equation (1) shows the importance of a module of elasticity. It is such (intended) stress that causes prolongation of the test-sample size by about its total original length $(\varepsilon=1)$. Modulus of elasticity is determined experimentally. The choice of method depends on the geometry of the test samples samples might be fibers, thin wires, strips, rods or thicker bars respectively beams. In the first case 
the test samples are subject to the tensile deformation, in the second case they are subject to the bending deformation. Depending on the type of loading, these methods are further divided to static and dynamic ones.

Presented contribution describes the determination of the Young's modulus on the basis of the deformation bar, which is activated by simple bending. The bar had a rectangular cross-section. One side of the bar was loaded by force and the other side of the bar was full fixed. Load force was realized by balance of known mass. According to the way of the loading, we might talk about a static method. Relative strains are determined by using measurement apparatus and measurement system Quantum X MX 840.

\section{Determination of the modulus of elasticity for the test sample (bar), which is loaded by simple bending}

In this method, we considered deformation of the body is caused by bending. Bar, full fixed on the one end, is loaded by bending moment, (from force $F$ ), Fig.1. The force $F$ causes the deflection of the bar. Deformation of bar due to its own weight might be considered to be very small and therefore it could be left. The neutral fiber that passes through the center of the cross-section and along the length of the bar have the same length in the undeformed and also in the deformed bar. The fibers above the neutral fiber are prolonged due to the tension by bending sample, fibers below the neutral fiber are shortened due to the pressure.

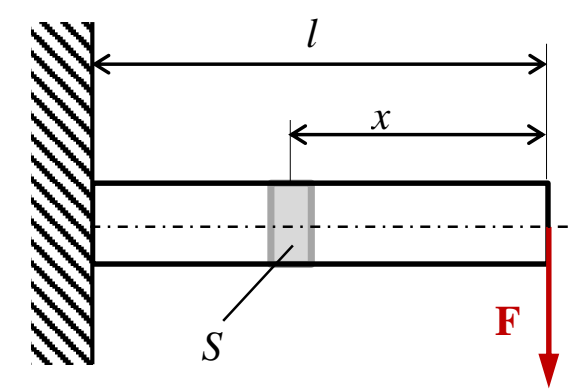

a)

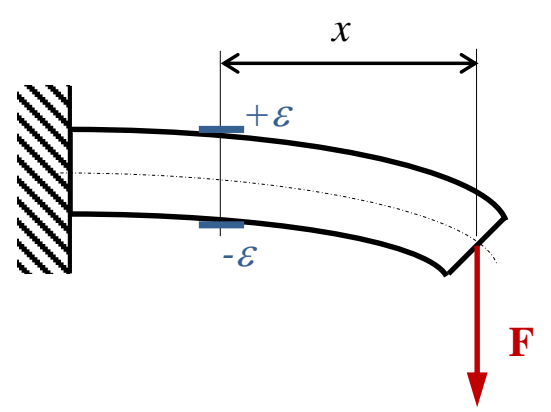

b)

Fig. 1 Loading and fixed of the bar a) undeformed shape; b) deformed shape

It is necessary to know the course of bending moments and transversal forces to determine the stress in each cross-section of bar. Based on the knowledge of elasticity, the size of bending moment in the distance $x$ (Fig. 1) is:

$$
M_{0}(x)=F \cdot x \text {, }
$$

where $M_{0}(x)[\mathrm{N} \cdot \mathrm{m}]$ is the bending moment, $F[\mathrm{~N}]$ is the loading force, $x[\mathrm{~m}]$ is the distance from free end bar.

Extreme normal stresses in given cross-section appears in edge fibers of cross-section $S$ ( $S=$ const.), Fig.2:

$$
\sigma_{\text {max }}=\frac{M_{0}(x)}{J_{z}} y_{\max }=\frac{M_{0}(x)}{W_{0}}
$$

where $J_{z}\left[\mathrm{~m}^{4}, \mathrm{~mm}^{4}\right]$ is second moment of area (for rectangular cross-section is $J_{z}=b \cdot h^{3} / 12$ ), $W_{0}\left[\mathrm{~m}^{3}\right.$, $\left.\mathrm{mm}^{3}\right]$ is section modulus in bending (for rectangular cross-section is $W_{0}=J_{z} / y_{\max }=b \cdot h^{2} / 6$ ), $y_{\max }=$ $h / 2$.

The shear stresses $\tau$ of shear force are null (by Fig. 2) for edge fibers of the bar [1]. The angle strain is null for the cross-section under simply bending only relative strain is created here. The size 
of the relative strain changes along section height according to the distance $y$ to the neutral axis (neutral fiber). Greatest prolongation $(+\varepsilon)$ respectively greatest shortening $(-\varepsilon)$ appears in extreme fibers, where is greatest normal stress [2].

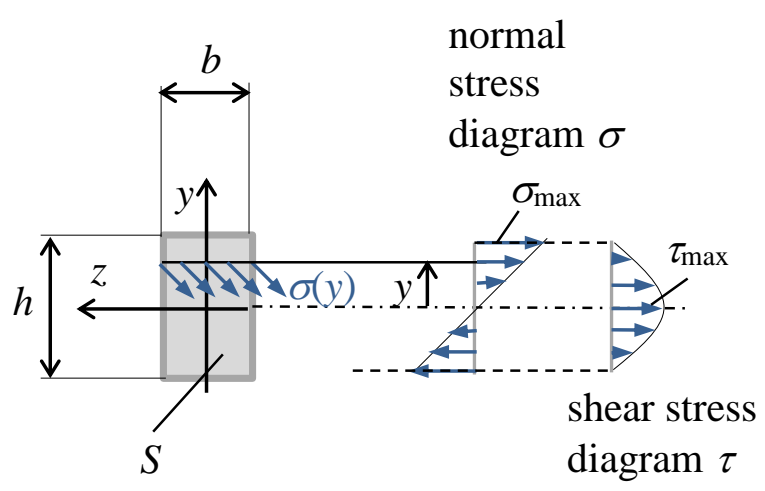

Fig. 2 The normal and shear stresses diagram in any rectangular cross-section of bar

If it is possible to measure the relative strain than, it is possible to determine modulus of elasticity test bars on the base of the following equations (1) to (3):

$$
E=\frac{\frac{M_{0}(x)}{W_{0}}}{\varepsilon}=\frac{F \cdot x}{\frac{b \cdot h^{2}}{6} \cdot \varepsilon}=\frac{6 F}{b \cdot h^{2}} \frac{x}{\varepsilon} .
$$

\section{The strain-gage measurement of relative strains}

Figure 3 shows the scheme of the measurement apparatus, which was formed to determine the dependence of the relative strains on loading. The bar of rectangular cross-section was used as test sample. One end of the bar was fixed attached to the metal frame, Fig. 4.

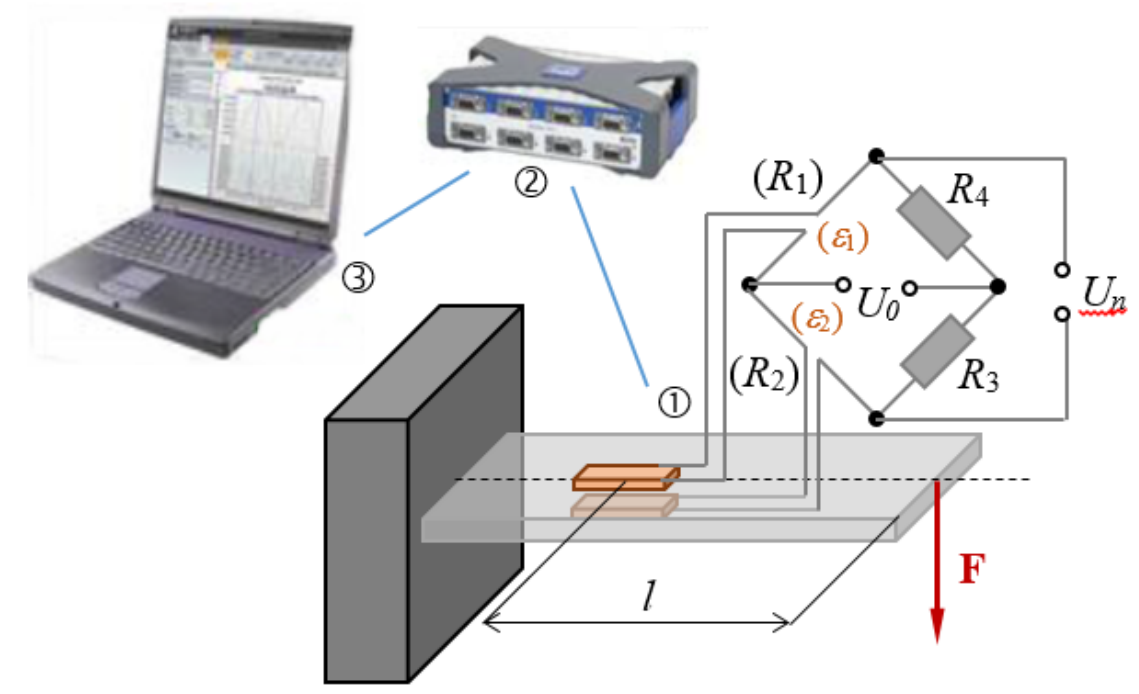

Fig. 3 The scheme of measurement apparatus

Weight was suspended on the free end of the bar, which created the force $F$ of size $F=m \cdot g$ ( $g$ is gravitational acceleration). Two strain gages were standardly glued to the surface of the test sample. One strain gage was glued on the upside of the bar at a distance $l$ from free end of the bar, Fig. 4 . Second strain gage was glued on the underside of the bar, at the same distance $l$ from free end of the bar. The axis of the strain gages were parallel with the neutral fiber of the bar. Measuring strain 
gauges were loaded by maximum normal stress and they could record the relatively strains on the surface of the bar. Measuring strain gauges (1) were linked in half bridge and connected to a universal measurement system QuantumX MX840 (2), which was controlled by computer (3). Program Catman Easy from firm HBM was used to record data, manage the measurement system and to process the obtained data $[2,3]$.
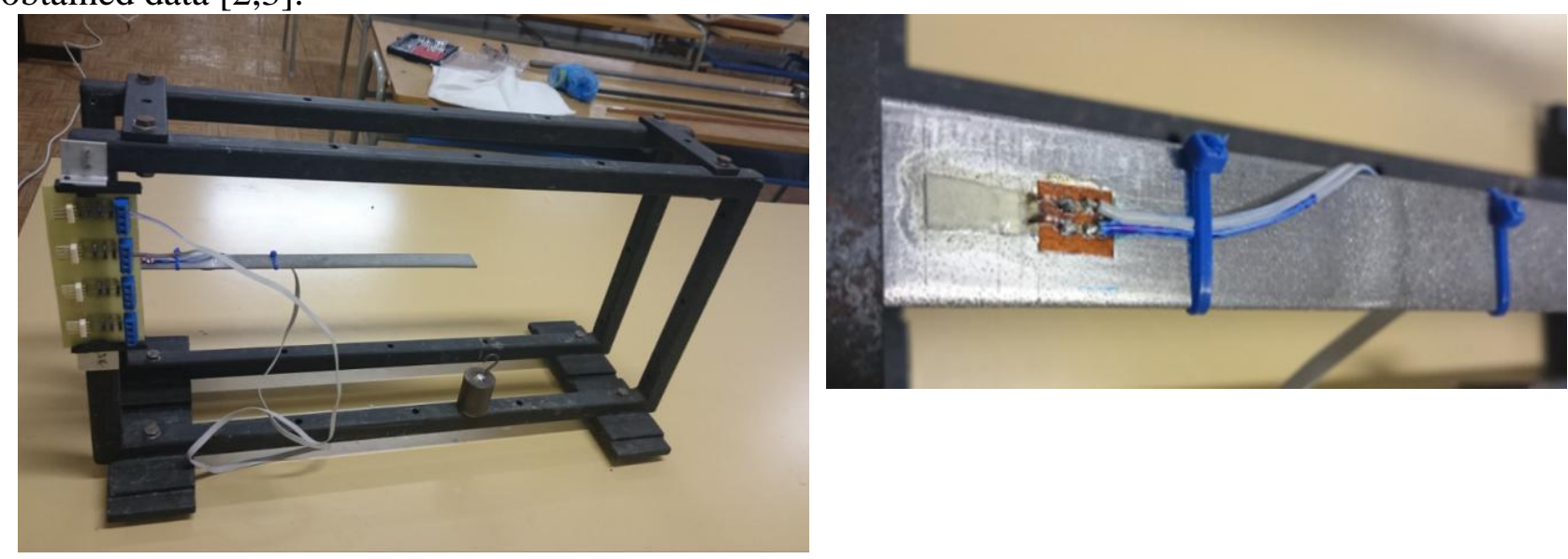

Fig. 4 Metal frame with a test sample and the view on strain gauge glued on the upside of the bar

Strain gauge transducers 6JP with ohmic value of $117 \Omega$ and with Gage factor $k=2.01$ were used for measures. Connection of sensors with a measuring system was performed using Ethernet cables. It is necessary to enter attach value of the Bridge factor to the program. Value of the Bridge factor reflects the involvement and number of strain gauges in the Wheatstone bridge, Fig. 3.

In practice, following equation can be used to determine the strain [4]:

$\frac{\Delta U_{0}}{U_{n}}=\frac{1}{4} k\left(\varepsilon_{1}-\varepsilon_{2}+\varepsilon_{3}-\varepsilon_{4}\right)=\frac{1}{4} k \varepsilon_{v}=B_{r} \frac{1}{4} k \varepsilon_{v}$,

where $U_{0}$ is output voltage, $U_{n}$ is driving voltage, $k$ is Gage Factor, $\varepsilon_{i}$ are individual relative strains, $\varepsilon_{v}$ is result strain, $B_{r}$ is Bridge Factor.

Also, Fig. 3 shows scheme of the Wheatstone bridge with two measuring strain gauges. Resistors $R_{1}$ a $R_{2}$ were replaced by measuring strain gauges. In a bridge:

$\varepsilon_{1}=-\varepsilon_{2} \neq 0$ a $\varepsilon_{3}=\varepsilon_{4}=0,\left|\varepsilon_{1}\right|=\left|\varepsilon_{2}\right|=\varepsilon_{V}$.

Substituting equation (6) into (5) we get:

$\frac{\Delta U_{0}}{U_{n}}=\frac{1}{4} k\left(\varepsilon_{1}-\varepsilon_{2}\right)=2 \frac{1}{4} k \varepsilon_{1}$.

From the last relationship we see that: $B_{r}=2 a \varepsilon_{v}=\varepsilon_{1}$.

\section{The calculation of the value of elasticity modulus}

Loading force was triggered by weights of mass $m=169.27 \cdot 10^{-3}[\mathrm{~kg}]$ and its size is: $F=m \cdot g=169.27 \cdot 10^{-3}[\mathrm{~kg}] \cdot 9.81\left[\mathrm{~m} \cdot s^{-2}\right]=1660.54 \cdot 10^{-3}[\mathrm{~N}]$.

The dimensions of the bar of rectangular cross-section are: width $b=19.55 \cdot 10^{-3}[\mathrm{~m}]$, thickenss $h=1.75 \cdot 10^{-3}[\mathrm{~m}]$.

Distance between axis strain gauges and line for application of the force: $l=257.50 \cdot 10^{-3}[\mathrm{~m}]$. The total length of the sample was $268 \cdot 10^{-3}$ [m].

Table 1 contains values of the relative strains obtained using the measurement system QuantumX MX840. 
Table 1 Measured and calculated values $\varepsilon$

\begin{tabular}{|c|c|c|c|}
\hline & $+\varepsilon$ (for tensile) $[\mathrm{m} / \mathrm{m}]$ & $-\varepsilon$ (for pressure) $[\mathrm{m} / \mathrm{m}]$ & $\varepsilon_{\mathrm{V}}[\mathrm{m} / \mathrm{m}]$ \\
\hline 1. measurement & 0.0002097 & 0.0002029 & 0.0002063 \\
\hline 2. measurement & 0.0002077 & 0.0001999 & 0.0002038 . \\
\hline 3. measurement & 0.0002083 & 0.0002025 & 0.0002054 \\
\hline \multicolumn{3}{|r|}{ average } & 0.00020517 \\
\hline
\end{tabular}

All measured values were substituted into relationship (4):

$E=\frac{6 F}{b \cdot h^{2}} \frac{l}{\varepsilon}=\frac{6 \cdot 1660.54 \cdot 10^{-3}}{19.55 \cdot 10^{-3} \cdot\left(1.75 \cdot 10^{-3}\right)^{2}} \frac{257.50 \cdot 10^{-3}}{0.00020517}=2.088 \cdot 10^{11}\left[\frac{\mathrm{N}}{\mathrm{m}^{2}}\right]=2.088 \cdot 10^{5}[\mathrm{MPa}]$.

Supplier of test sample declared that the size the modulus of elasticity is $2.1 \cdot 10^{5} \mathrm{MPa}$. By this method we obtained value of the relative error $0.57 \%$ using determination $E$. The obtained value is accurate sufficiently. Mechanical table declares value of the modulus of elasticity for hauled steel in range (1.9 to 2.15$) \cdot 10^{5} \mathrm{MPa}$. The obtained value is located in the given range.

\section{Summary}

The contribution deals with determination of the shear modulus for bar with rectangular crosssections with the unknown material properties. Relative strains were detected experimentally for given loading force, more measurements were realized at shorter time intervals. The bar was loaded under simple bending. Young modulus was calculated by relations of the elementary elasticity using the obtained measured values. To experimentally obtain the unit less strain tenzometric sensors connected to half bridge and universal measurement system QuantumX MX840 were used.

The described method enables to determine the modulus of elasticity for the test samples of unknown material properties in the laboratory. This method is suitable for inclusion in the teaching process at the technical universities. Thus, the students have the opportunity to see the link between theory and practice and to gain practical skills with universal measurement system.

\section{Acknowledgement}

This work has been supported by the Grants Agency of the Slovak republic VEGA under the Grant No. 1/0184/14. This publication is the result of implementation of the project: "University Scientific Park: CAMPUS MTF STU - CAMBO" (ITMS: 26220220179) supported by the Research \& Development Operational Program funded by the EFRR.

\section{References}

1. JANÍČEK, P., ONDRÁČEK, E., VRBKA, J. Solid mechanics, Elasticity and strength I, Brno, VUT Brno, 1992, ISBN 80-214-0468-X.

2. GERE, J. M., GOODNO, B. J. Mechanics of Materials, Seventh Edition, Quebecor World, USA, 2009.

3. ŠTURCEL, J. Sensors and transducers, Bratislava, STU Bratislava, 2002, ISBN 80-227-1712-6.

4. Information on http://ean2011.fme.vutbr.cz/img/fckeditor/file/opory/Experimentalni_mechanika.pdf

\section{Address:}

Eva Labašová, Ing. Ph.D.,

Institute of Applied Informatics, Automation and Mechatronics, Faculty of Materials Science and Technology in Trnava, STU in Bratislava, Bottova 25, 91724 Trnava, SR, e-mail: eva.labasova@ @stuba.sk

Vladimír Labaš, doc. RNDr. Ph.D.,

Institute of Materials Science, The faculty of Materials Science and Technology in Trnava, STU in Bratislava, Bottova 25, 91724 Trnava, SR, tel.: 00421906068 390, e-mail: vladimir.labas@ @tuba.sk 